JURNAL PANGAN DAN GIZI 9 (1): 39-52, April 2019

ISSN 2086-6429 (Online)

Tersedia online di http://jurnal.unimus.ac.id/index.php/JPDG

\title{
Pengaruh Lama Perkecambahan Terhadap Rendemen, Kadar Antosianin, Vitamin E dan Aktivitas Antioksidan Kecambah Kedelai Hitam
}

\section{The Influence of Long Germination to Rendement, Antosianin, Vitamin E Levels and Antioxidant Activity on Black Soybean Sprouts}

\author{
Siti Asropah, Nurrahman, Wikanastri Hersoelistyorini \\ Program Studi S1 Teknologi Pangan, Fakultas Ilmu Keperawatan dan Kesehatan \\ Univesitas Muhammadiyah Semarang \\ Email: asropahs@yahoo.com
}

\begin{abstract}
Germination process can increase the nutritional value and functional properties that exist in the grain. Black soybeans contains anthocyanin, vitamin $E$ and antioxidant activity that is beneficial to health. This study aims to determine the effect of long germination on rendement, anthocyanin, vitamin E levels and antioxidant activity on black soybean sprouts. Preliminary studies includes optimalization the length of germination and characterization of black soybean seeds. The main research includes physical and chemical analysis of rendement measurement, anthocyanin content, vitamin $E$ content and antioxidant activity. Then, analysis of proximate content on black soybean sprouts best result from long treatment of germination. The data measurement of black soybeans sprouts was obtained a digital scales and spectrophotometer UV-Vis. The results showed that (1) The germination has an effect on rendement, anthocyanin, vitamin E levels and antioxidant activity on black soybean sprouts. (2) In 40 hours long germination treatment showed anthocyanin level (91.84 mg / 10 g) and antioxidant activity (24.51\% RSA) has the highest value. (3) The longer of germination has higher value on rendement percentage and vitamin E content.

Keywords: Black Soybean, Sprout, Anthocyanin, Vitamin E and Antioxidant Activity
\end{abstract}

PENDAHULUAN

Proses perkecambahan

merupakan suatu rangkaian kompleks

dari perubahan-perubahan morfologi,

fisiologi dan biokimia yang dapat

meningkatkan nilai gizi seperti antioksidan,

vitamin E dan bahan kimia nabati yang ada dalam biji. Menurut Anita (2009),

biji perkecambahan dapat meningkatkan rendemen tepung kacang komak, dari 14,01 persen untuk tepung kacang komak tidak dikecambahkan meningkat menjadi 27,77 persen untuk tepung kecambah kacang komak. Proses perkecambahan kedelai hitam 
ini diharapkan dapat meningkatkan bahan baku yang akan dikecambahkan.

rendemen kecambah kedelai hitam. Proses perkecambahan juga dapat meningkatkan aktivitas antioksidan sebesar 8,32 persen pada kecambah kacang tunggak (Ningsih, 2007). Pada penelitian Anggrahini (2007), menunjukkan bahwa semakin lama perkecambahan pada kecambah kacang hijau produksi vitamin $\mathrm{E}$ akan semakin meningkat. Pada perlakuan perkecambahan 0,12 dan 24 jam tidak terdeteksi adanya vitamin E. Peningkatan vitamin $\mathrm{E}$ terjadi pada perlakuan perkecambahan 36 dan 48 jam yaitu dari $0,21 \mu \mathrm{g} / \mathrm{g}$ meningkat menjadi $0,53 \mu \mathrm{g} / \mathrm{g}$.

Biji kedelai diketahui mengandung vitamin E sebesar 1,78 mg/10 g berat bahan (Zakaria et al., 2000). Nurrahman (2015), melaporkan bahwa satu-satunya varietas kedelai yang memiliki kandungan antosianin dalam kulitnya sebagai antioksidan adalah kedelai hitam yaitu sebesar 222,49 mg/100 g sedangkan varietas kedelai lain tidak memilikinya. Oleh karena itu, dipilihlah kedelai hitam sebagai
Tujuan dari penelitian ini adalah untuk mengetahui pengaruh variasi lama perkecambahan terhadap rendemen, kadar antosianin, vitamin E dan aktivitas antioksidan kecambah kedelai hitam.

\section{BAHAN DAN METODE}

\section{Bahan}

Bahan utama dalam pembuatan kecambah kedelai hitam adalah kedelai hitam varietas Dentam 1 yang diperoleh dari UPBS Balitkabi Malang.

\section{Prosedur Pembuatan Kecambah Kedelai}

Hitam (Aminah dan Hersoelistyorini, 2012)

Kedelai hitam ditimbang $100 \mathrm{~g}$ kemudian direndam dalam larutan alginat 2 persen selama 2 jam pada suhu ruang, selanjutnya dicuci dengan air mengalir, lalu ditiriskan, ditutup dengan kain dan dikecambahkan. Selama proses perkecambahan dilakukan penyiraman setiap 4 jam sekali. 
Pengukuran Rendemen (Ali dan Lalu sentrifuge sehingga ekstrak dan

Arqomah, 2013)

Pengukuran rendemen dengan

menggunakan timbangan digital SF-400.

Persen rendemen dihitung dengan

menggunakan persamaan:

$\%$ Rendemen $=\frac{A-B}{A} \times 100 \%$

Keterangan:

$\mathrm{A}=$ berat sampel sebelum perlakuan

perkecambahan

$\mathrm{B}=$ berat sampel setelah perlakuan

perkecambahan

Analisa Antosianin (AOAC, 2005)

Sampel dikeringkan dengan oven suhu $60^{\circ} \mathrm{C}$ selama 72 jam. Kemudian diayak dengan ayakan 100 mesh untuk memperoleh ukuran partikel yang sama. Sampel ditimbang sebanyak $0,4 \quad \mathrm{~g}$ kemudian ditambah buffer asetat $1 \mathrm{~mL}$, selanjutnya diinkubasi pada suhu $40^{\circ} \mathrm{C}$ selama 60 jam dengan pengocokan 170 rpm. Setelah inkubasi tambahkan $10 \mathrm{~mL}$ metanol $70 \%$ yang telah diasamkan $\mathrm{pH}$ 3,5. Selanjutnya dimasukkan dalam penangas air suhu $80^{\circ} \mathrm{C}$ selama 1 jam. residunya terpisah. Penggulangan dilakukan 3 kali. Untuk larutan pH 1,0 dibuat dengan $0,186 \mathrm{~g} \mathrm{KCl}$ dimasukkan dalam beker gelas, kemudian ditambah $100 \mathrm{~mL}$ aquades dan $\mathrm{HCl}$ pekat sedikit demi sedikit sampai pH larutan menjadi 1,0. Sedangkan untuk larutan $\mathrm{pH}$ 4,5 dibuat dengan cara menimbang 5,443 g $\mathrm{CH}_{3} \mathrm{COONa} .3 \mathrm{H}_{2} \mathrm{O}$ dimasukkan dalam beker gelas ditambah $100 \mathrm{~mL}$ aquades. Selanjutnya ditambah $\mathrm{HCl} 2 \mathrm{~N}$ sedikit demi sedikit sehingga $\mathrm{pH}$ menjadi $\mathrm{pH}$ 4,5. Pengukuran absorbansi dilakukan menggunakan spektrofotometer UV-Vis menggunakan panjang gelombang $520 \mathrm{~nm}$ dan $700 \mathrm{~nm}$. Rumus perhitungan pigmen antosianin adalah sebagai berikut:

Antosianin pigmen $\left(\frac{\mathrm{mg}}{100 \mathrm{~g}}\right)$

$$
=\frac{\mathrm{A} \times \mathrm{MW} \times D F \times 10^{3}}{\varepsilon \times 1}
$$

Keterangan :

$\mathrm{A}=\left(\mathrm{A}_{520 \mathrm{~nm}}-\mathrm{A}_{700 \mathrm{~nm}}\right)$ $\mathrm{pH}=1,0-4,5\left(\mathrm{~A}_{520 \mathrm{~nm}}-\mathrm{A}_{700 \mathrm{~nm}}\right)$ $\mathrm{MW}=449,2 \mathrm{~g} / \mathrm{mol}$

$\mathrm{DF}=$ Dilution Factor $\varepsilon=26.900 \mathrm{~mol}$ 
Analisa Vitamin E (Andulaa et al., 2017)

Pengujian ini dilakukan melalui enam tahapan yaitu: 1) Pembuatan larutan induk standar vitamin E konsentrasi 100 ppm 2) Menimbang $0,01 \mathrm{~g}$ vitamin $\mathrm{E}$ murni, melarutkannya dengan heksan dan memasukkan ke dalam labu ukur $100 \mathrm{~mL}$ dan ditambahkan heksan hingga tanda batas. 3) Pembuatan seri larutan standar dengan mengencerkan larutan standar induk 100 ppm dengan heksan pada masingmasing labu ukur $25 \mathrm{~mL}$ dengan konsentrasi 12,5; 17,5; 25 dan 50 ppm. 4) Larutan baku diukur absorbansinya untuk menentukan panjang gelombang maksimum pada kisaran $280-328 \mathrm{~nm}$ menggunakan spektrofotometer UV-Vis. Panjang gelombang maksimum yang diperoleh ditentukan dari nilai absorban tertinggi. 5) Pembuatan kurva standar yaitu mengukur absorbansi seri larutan standar 12,$5 ; 17,5 ; 25$ dan 50 ppm pada panjang gelombang maksimum kemudian dibuat kurva baku, dimana absorban sebagai ordinat dan konsentrasi sebagai absis. Dari kurva baku ini diperoleh persamaan linear $y=a x+b$. 6) Penentuan konsentrasi sampel dengan melakukan pengukuran absorbansi terhadap ekstrak vitamin E hasil ekstraksi. Nilai absorbansi yang diperoleh digunakan untuk menghitung konsentrasi vitamin $\mathrm{E}$ dengan menggunakan persamaan garis linear regresi dari kurva kalibrasi/standar yang telah dibuat sehingga bisa diketahui konsentrasi sampel. Rumus perhitungan kadar vitamin $\mathrm{E}$ adalah sebagai berikut:

Kadar $\propto$ tokoferol $\left(\frac{\mu \mathrm{g}}{100 \mathrm{~g}}\right)$

$=\frac{x\left(\frac{\mu}{L}\right) \cdot \text { Volume }(L)}{\text { berat sampel }} \times F P \times 100 \mathrm{~g}$

Analisa Antioksidan (Xu dan Chang, 2007)

Analisa antioksidan dilakukan dengan cara menimbang $0,5 \mathrm{~g}$ sampel kemudian ekstraksi dengan $10 \mathrm{ml}$ metanol. $1 \mathrm{ml}$ sampel hasil ekstraksi selanjutnya ditambah 3,8 mL larutan DPPH 0,16 mM lalu dikocok selama 1 menit kemudian didiamkan pada ruang gelap selama 30 menit. Pembacaan 
absorbansi sampel dilakukan dengan menggunakan spektrofotometer UV-Vis pada panjang gelombang $517 \mathrm{~nm}$. Persentase aktivitas antioksidan pada kecambah kedelai hitam dinyatakan dalam satuan persen RSA (Radical Scavenging Activity). Scavenging effect DPPH dihitung dengan rumus:

Scavenging effect $(\% \mathrm{RSA})=1-$ $\frac{\text { Absorban sampel }}{\text { Absorban blangko }} \times 100 \%$

\section{HASIL DAN PEMBAHASAN}

\section{Optimalisai Lama Perkecambahan}

Percobaan

perlakuan

lama

perkecambahan $0,8,16,24,32,40,48,56$ dan 64 jam mengahsilkan 4 perlakuan terbaik sebagai variabel penelitian yaitu pada perlakuan lama perkecambahan 24, 32, 40 dan 48 jam dengan pertimbangan kecambah yang dihasilkan sesuai sifat sensori kecambah berdasarkan penampakan kecambah yang tidak terlalu panjang dan tidak memiliki percabangan akar.

\section{Karakterisasi Biji Kedelai Hitam}

Biji kedelai hitam varietas Dentam 1 diketahui memiliki kadar antosianin, kadar vitamin $\mathrm{E}$ dan aktivitas antioksidan yang cukup tinggi. Rata-rata kadar antosianin pada biji kedelai hitam Dentam 1 sebesar 609,48 mg/100 g, kadar vitamin $\mathrm{E}$ berkisaran antara 42,31 ( $\mu \mathrm{g} / 100 \mathrm{~g})$, sedangkan hasil perhitungan aktivitas antioksidan yaitu sebesar 8,62 persen RSA.

Satu-satunya varietas kedelai yang memiliki kandungan antosianin di dalamnya adalah kedelai hitam. Kedelai hitam varietas Mallika memiliki kandungan antosianin yaitu sebesar 222,49 mg/100 g (Nurrahman, 2015). Sedangkan kedelai hitam varietas Dentam 1 memiliki kadar antosianin sebesar 609,4 mg/100 g lebih tinggi dibandingkan dengan kedelai hitam varietas Mallika. Pada penelitian kecambah kacang hijau perlakuan 0, 12, dan 24 jam tidak terdeteksi adanya vitamin E. Peningkatan kadar vitamin E terjadi pada perkecambahan 36 dan 48 jam yaitu sebesar $0,21 \mu \mathrm{g} / \mathrm{g}$ dan $0.53 \mu \mathrm{g} / \mathrm{g}$ (Anggrahini, 2007). Sedangkan pada biji kedelai hitam varietas Dentam 1 memiliki kadar vitamin E yaitu sebesar 42,31 $\mu \mathrm{g} / 100$ g lebih tinggi dibandingkan dengan biji kacang hijau sebelum dikecambahkan. Lama 
perkecambahan berpengaruh terhadap persen. Peningkatan persentase nilai aktivitas antioksidan. Aktivitas antioksidan rendemen pada penelitian ini terjadi seiring pada kecambah perlakuan 64 jam sebesar bertambahnya waktu perkecambahan. 28,241 persen (Pertiwi et al., 2013). Semakin lama perkecambahan menunjukkan Sedangkan pada biji kedelai hitam Dentam 1 kecenderungan persentase rendemen yang ini memiliki aktivitas antioksidan lebih semakin meningkat.

rendah yaitu sebesar 8,62 persen RSA.

\section{Rendemen}

Lama perkecambahan mempunyai pengaruh terhadap persentase peningkatan nilai rendemen pada kecambah kedelai hitam. Semakin lama perkecambahan menunjukkan persentase rendemen yang semakin meningkat. Persentase nilai kali lebih banyak dibandingkan dengan rendemen pada perlakuan lama persentase rendemen sebelum perkecambahan 24 jam yaitu sebesar 4,7 dikecambahkan.

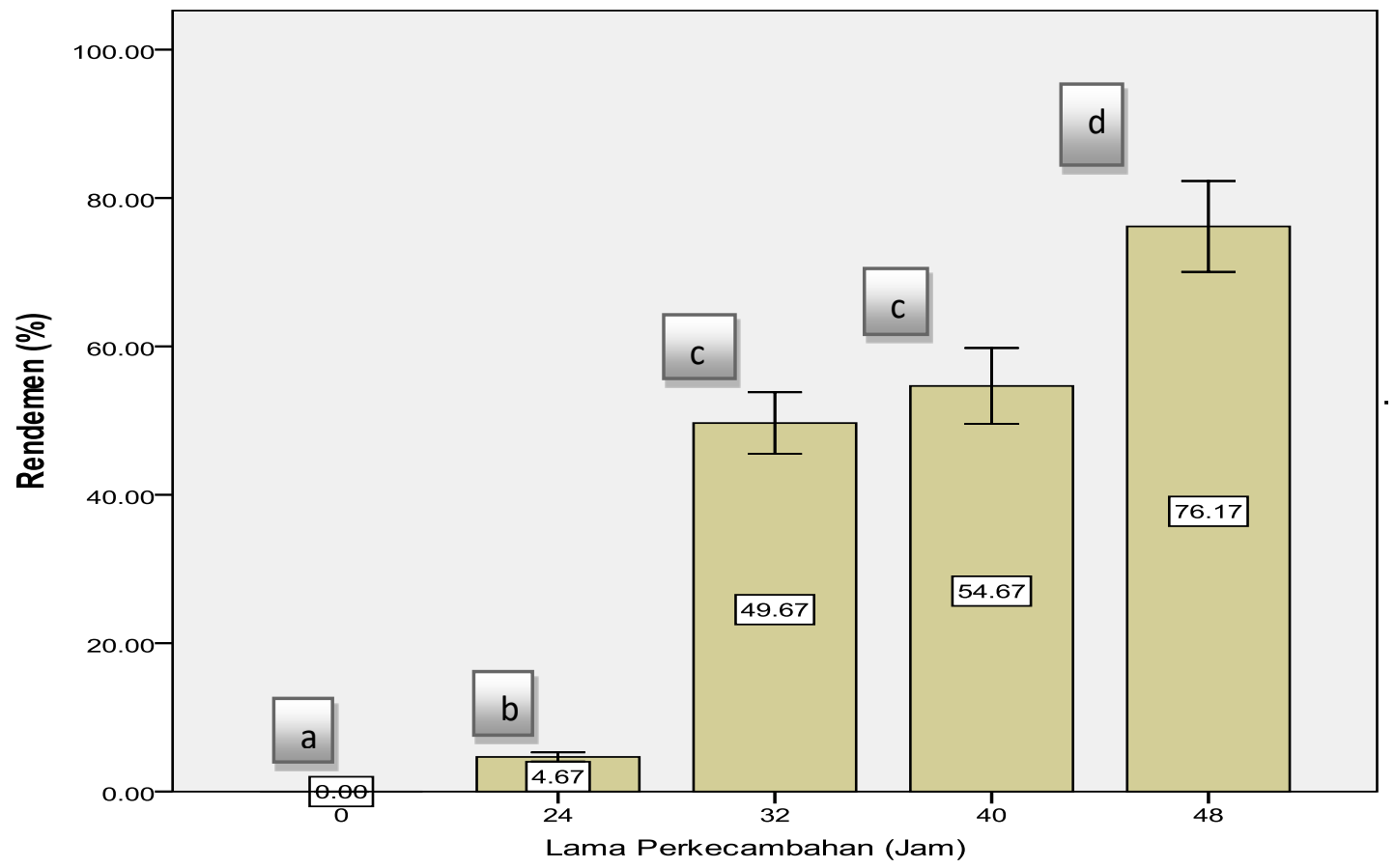


Gambar 1. Rendemen kecambah kedelai hitam variasi lama perkecambahan

Hasil uji ANOVA pengamatan rendemen kecambah kedelai hitam pada masingmasing perlakuan menunjukkan adanya perbedaan (p-value $0,00<0,05) . \quad$ Pada perlakuan 0 jam menunjukkan perbedaan signifikan terhadap perlakuan 24, 32, 40 dan 48 jam. Perlakuan 24 jam berbeda signifikan terhadap masing-masing perlakuan. Perlakuan lama perkecambahan 32 dan 40 jam tidak berbeda signifikan, namun berbeda signifikan terhadap perlakuan lain. Perlakuan lama perkecambahan 48 jam berbeda signifikan terhadap masing-masing perlakuan.

Perkecambahan dipengaruhi oleh beberapa faktor diantaranya yaitu faktor internal dan faktor ekternal. Faktor internal meliputi tingkat kemasakan fisiologi, ukuran, dormasi dan inhibitor. Sedangkan faktor eksternal meliputi ketersediaan air, suhu, kondisi media, oksigen dan cahaya (Pandu, 2016). Faktor-faktor yang mempengaruhi perkecambahan biji pada penelitian ini telah dikendalikan. Faktor internal yang meliputi tingkat kemasakan fisiologis, ukuran benih, dormasi dan inhibitor dikendalikan melalui pemilihan benih-benih unggul varietas Dentam 1 . Faktor eksternal yang meliputi ketersediaan air, suhu, kondisi media, oksigen, dan cahaya dalam penelitian ini juga dikendalikan sehigga menghasilkan kecambah yang baik secara fisik dan sensorinya. Ketersediaan air dicukupi dengan cara penyiraman biji setiap 4 jam sekali. Suhu dikendalikan pada $35,5^{\circ} \mathrm{C}$ (suhu ruang) yang optimal dalam proses perkecambahan (Aminah dan Hersoelistyorini, 2012). Kondisi media dikendalikan dengan cara melapisi wadah dengan kapas steril sehingga media tetap lembab dan terhidar dari mikroba yang tidak menguntungkan. Oksigen dan cahaya dikondisikan agar tetap stabil dengan cara menutup wadah dengan kain yang agak gelap. Penutupan media perkecambahan dengan kain diusahakan tidak terlalu rapat sehingga oksigen di dalamnya terpenuhi. 
Upaya peningkatkan persentase

rendemen kecambah juga dilakukan dengan penambahan nutrisi berupa natrium alginat sebesar 2 persen. Pemberian nutrisi berupa natrium alginat 2 persen dalam proses perkecambahan dapat meningkatkan produktifitas kecambah (Andarwulan dan Hariyadi, 2004). Pemberian natrium alginat konsentrasi 2 persen lebih optimal dibandingkan dengan dengan konsentrasi 1 dan 3 persen dalam peningkatan daya perkecambahan (Sumaryono dan Saptari, 2015). Pada penelitian ini menunjukkan pemberian natrium alginat sebanyak 2 persen menunjukkan hasil perhitungan rendemen yang positif pada masing-masing perlakuan perkecambahan. Semakin lama perkecambahan rendemen akan semakin meningkat dapat dilihat juga dari pertumbuhan kecambah kedelai hitam yang semakin lama semakin memanjang.

\section{Kadar Antosianin}

Lama perkecambahan berpengaruh terhadap kadar antosianin pada kecambah kedelai hitam. Kadar antosianin pada perlakuan lama perkecambahan menunjukkan bahwa semakin lama perkecambahan kadar antosianin cenderung meningkat. Peningkatan kadar antosianin tertinggi adalah pada perlakuan lama perkecambahan 40 jam. Satu-satunya varietas kedelai yang memiliki kandungan antosianin didalamnya adalah kedelai hitam (Nurrahman, 2015). Pada penelitian ini biji kedelai hitam varietas Dentam 1 memiliki kadar antosianin sebesar 609,5 mg/100 g kemudian kadar antosianin meningkat setelah perlakuan lama perkecambahan 24 jam yaitu sebesar 673,5 mg/100 g dan mengalami kecenderungan peningkatan pada lama perkecambahan 30 dan 40 jam, namun pada lama perkecambahan 48 jam mengalami penurunan. 


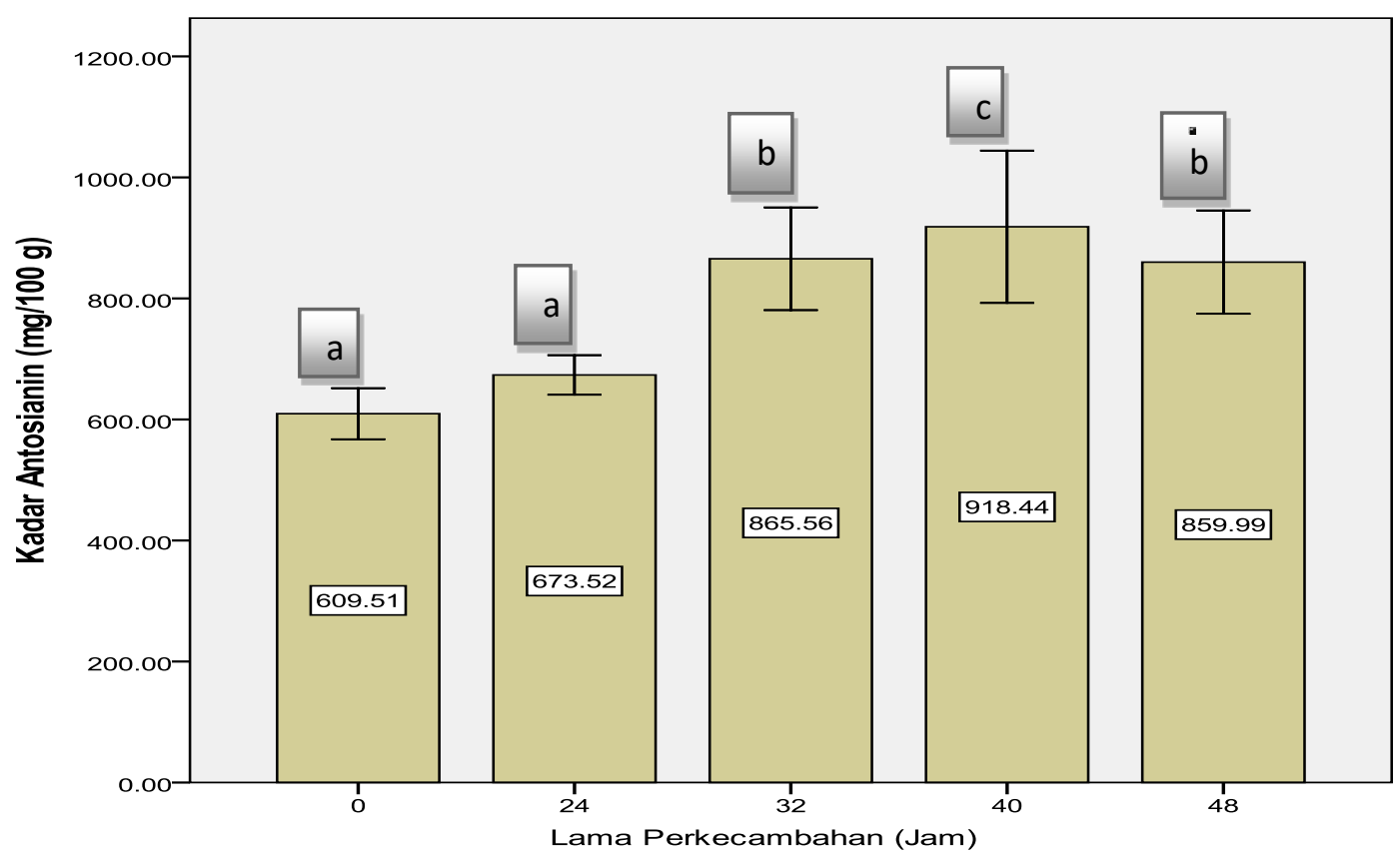

Gambar 2. Kadar antosianin kecambah kedelai hitam variasi lama perkecambahan

Lama perkecambahan 32, 40 dan 48 jam berbeda signifikan terhadap perlakuan lama perkecambahan 0 dan 24 jam. Perlakuan lama perkecambahan 32 dan 48 jam tidak berbeda signifikan namun berbeda signifikan terhadap 0, 24 dan 40 jam. Perlakuan 40 jam berbeda siginifikan terhadap masing-masing perlakuan $\quad(\mathrm{p}-$ value $=0,05 \leq 0,05) . \quad$ Stabilitas kadar antosianin sangat tergantung pada penyimpanan dan pemprosesan (Rein, 2005). Kestabilan antosianin dipengaruhi oleh beberapa faktor antara lain suhu, lama penyimpanan, $\mathrm{pH}$ dan penanganan lain (Suhartatik et al., 2013). Faktor-faktor tersebut dimungkinkan mempengaruhi peningkatan kadar antosianin selama perlakuan lama perkecambahan.

Aktivitas enzim pada perkecambahan biji dipengaruhi oleh ketersediaan air. Penyerapan air akan mengaktifkan enzim yang tersimpan dan menstimulasi pertumbuhan. Enzim menghidrolisis sebagian zat cadangan menjadi energi, menurunkan berat molekul dan senyawa larut yang digunakan dalam memproduksi sel jaringan (Pessarakli, 2001). Kerusakan enzim atau hidrolisis enzim dapat terjadi akibat penambahan molekul air yang banyak (Sinha, 2004). Ketersediaan air berpengaruh terhadap aktivitas enzim dalam 
menghidrolisis komponen zat gizi pada biji perkecambahan dapat meningkatkan untuk mengahasilkan enzim-subtrat dalam produksi vitamin E. Hasil pengamatan kadar meningkatkan produk baru yang dihasilkan. vitamin $\mathrm{E}$ pada perlakuan perkecambahan

Kadar Vitamin E

Kedelai hitam varietas Dentam 1 perkecambahan semakin meningkatkan memiliki kandungan vitamin E sebesar kadar vitamin E. Kadar vitamin E tertinggi 42,32 $\mu \mathrm{g} / 100 \quad \mathrm{~g}$ kemudian mengalami adalah pada perlakuan perkecambaahan 48 peningkatan setelah proses perkecambahan. jam yaitu sebesar 78,86 $\mu \mathrm{g} / 100 \mathrm{~g}$. Pada Semakin lama perkecambahan yaitu pada perlakuan sebelum perkecambahan 24, 32, 40 dan 48 jam menunjukkan kadar menunjukkan kadar vitamin E sebesar 42,32 vitamin E yang semakin meningkat. Lama $\mu \mathrm{g} / 100 \mathrm{~g}$, kemudian semakin meningkat perkecambahan berpengaruh terhadap pada perlakuan perkecambahan $24,32,40$ peningkatan kadar vitamin E. Proses dan 48 jam.

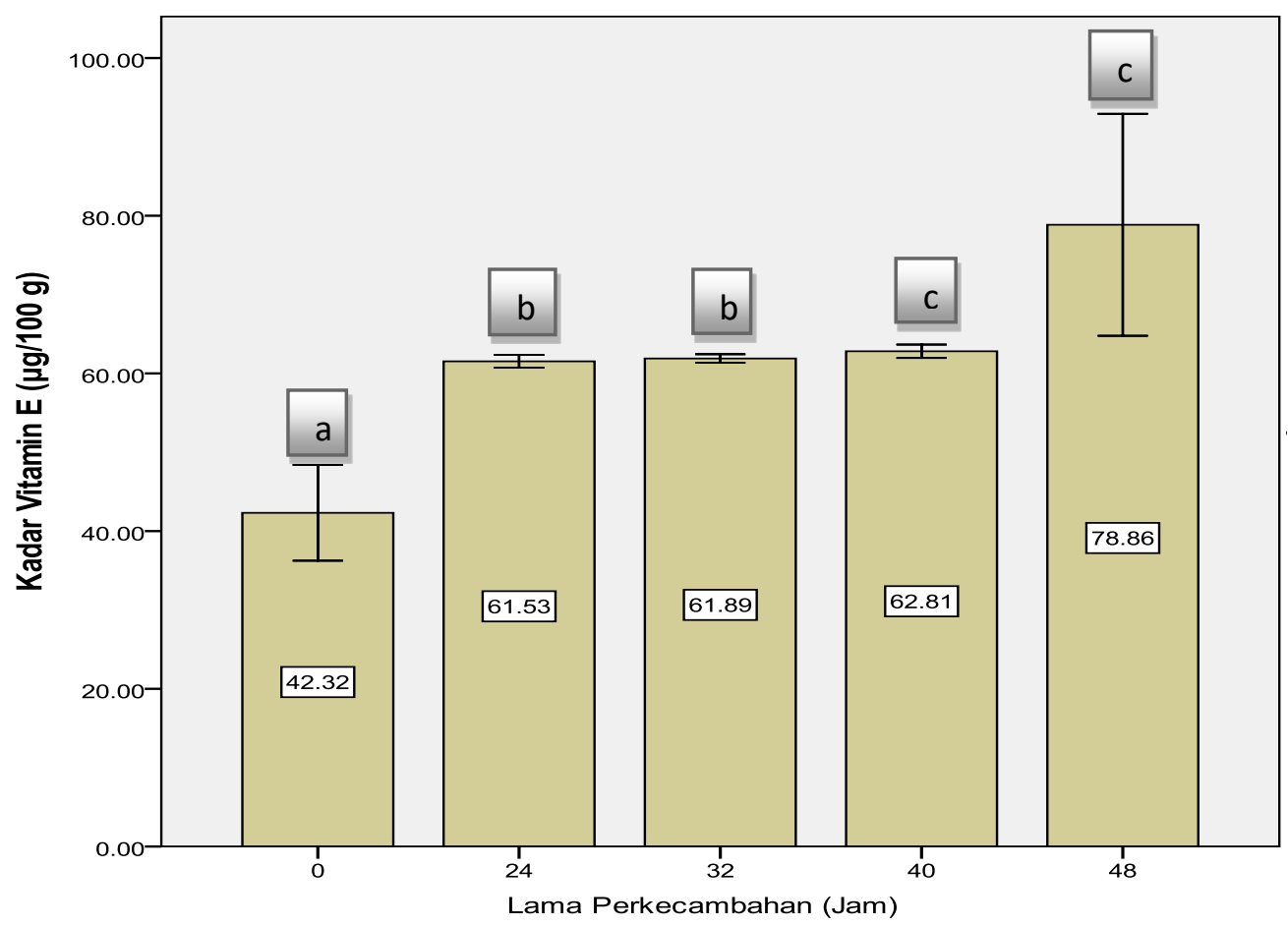

Gambar 3. Kadar vitamin E pada variasi perlakuan lama perkecambahan 
Pada perlakuan lama perkecambahan 0 jam berbeda signifikan terhadap perlakuan lama perkecambahan 24, 32, 40 dan 48 jam (p-value $=0,02<0,05) . \quad$ Perlakuan lama perkecambahan 24 dan 32 jam tidak berbeda signifikan, namun berbeda signifikan terhadap perlakuan lain. Perlakuan lama perkecambahan 40 dan 48 jam tidak berbeda signifikan namun berbeda signifikan terhadap perlakuan lain. Lama perkecambahan berpengaruh terhadap peningkatan kadar vitamin E. Semakin lama perkecambahan kadar vitamin E akan semakin meningkat (Anggrahini, 2007).

Vitamin E stabil dalam kondisi asam dan basa (Tanuatmojo, 2015). Vitamin E juga menunjukkan stabilitas yang cukup baik dalam ketiadaan oksigen dan pengoksidasi lipid (Sugiharto, 2013). Kerusakan vitamin E dapat terjadi pada proses pengolahan dan penanganan yang bersifat komersial termasuk pembekuan (Triana, 2006). Stabilitas vitamin E menunjukkan hasil positif terhadap peningkatan kadar vitamin $\mathrm{E}$ selama perlakuan lama perkecambahan.
Pada penelitian sebelumnya menunjukkan penurunan kadar vitamin E kecambah kedelai kuning terjadi saat umur perkecambahan 64 jam kemudian berturutturut menurun pada umur perkecambahan 72 dan 80 jam (Laila, 2008). Pada penelitian kecambah kedelai hitam ini umur perkecambahan 48 jam masih efisien produktifitasnya dalam peningkatan kadar vitamin E.

\section{Aktivitas Antioksidan}

Aktivitas antioksidan pada perlakuan lama perkecambahan dari hasil pengamatan menunjukkan hasil yang cenderung meningkat pada perlakuan lama perkecambahan 24, 32 dan 40 jam, namun mengalami penurunan pada perlakuan perkecambahan 48 jam. Aktivitas antioksidan stabil pada $\mathrm{pH}$ netral (7) dan suhu $28^{\circ} \mathrm{C}$ (Karseno dan Setyawati, 2013). Pada penelitian ini proses perkecambahan dilakukan pada suhu ruang yaitu $35,5^{\circ} \mathrm{C}$. Ketidakstabilan peningkatan aktivitas antioksidan dimungkinkan terjadi akibat peningkatan suhu selama proses 
perkecambahan sehingga aktivitas perkecambahan 48 jam menurun. antioksidan pada perlakuan lama

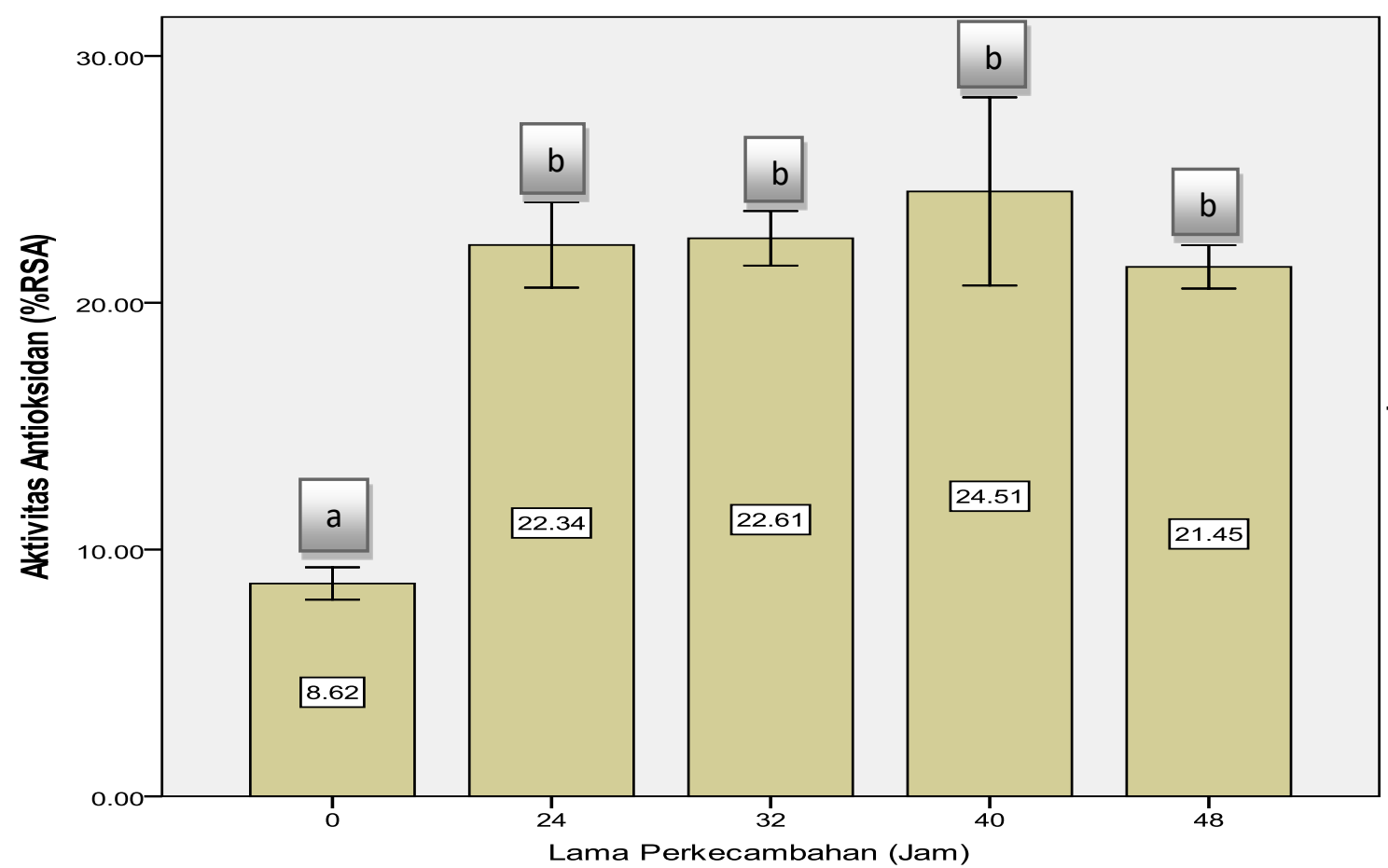

Gambar 4. Aktivitas antioksidan kecambah kedelai hitam variasi lama perkecambahan

Pada perlakuan lama perkecambahan 24, kedelai hitam yang berperan sebagai 32, 40 dan 48 jam berbeda signifikan senyawa antioksidan.

terhadap perlakuan lama perkecambahan 0 jam (p-value $=0,00<0,05)$, namun pada masing-masing perlakuan tidak ada beda. Peningkatan sifat fungsional pada biji terjadi akibat adanya pengaktifan sel selama perkecambahan (Winarsi, 2010). Peningkatan aktivitas antioksidan juga dikaitkan dengan adanya peningkatan antosianin dan vitamin E pada kecambah

\section{KESIMPULAN}

Perkecambahan berpengaruh terhadap rendemen, kadar antosianin, kadar vitamin $\mathrm{E}$ dan aktivitas antioksidan pada kecambah kedelai hitam. Perlakuan terbaik pada kecambah kedelai hitam adalah perlakuan lama perkecambahan 40 jam. 


\section{DAFTAR PUSTAKA}

Ali, F., Ferawati dan Arqomah, R. 2013. Ekstraksi Zat Warna dari Kelopak Bunga Rosella (Studi Pengaruh Konsentrasi Asam Asetat dan Asam Sitrat). Jurnal Teknik Kimia No. 1, Vol. 19: 26 - 34.

Aminah, S. dan Hersoelistyorini, W. 2012. Karakteristik Kimia Tepung Kecambah Serealia dan Kacang-kacangan dengan Variasi Blancing. Di dalam: Seminar Hasil-hasil Penelitian - LPPM UNIMUS.

Andarwulan, N. dan Hariyadi, P. 2004. Optimasi Produksi Antioksidan pada Proses Perkecambahan Biji-bijian dan Diversifikasi Produk Pangan Fungsional dari Kecambah yang Dihasilkan. Jurnal Teknologi Pertanian: $1-2$.

Andulaa, A. M., Ruslan, Hardi, Y. dan Puspitasari, D. J. 2017. Studi Perbandingan Analisis Vitamin E minyak Sawit Merah Tersaponifikasi Antara Metode Spektrofotometri UVVis dan KCKT. Jurnal Kovalen, 3 (1): 50 -57 .

Anggrahini, S. 2007. Pengaruh Lama Pengecambahan Terhadap Kandungan $\alpha$ Tokoferol dan Senyawa Proksimat Kecambah Kacang Hijau (Phaseolus radiates L.). Jurnal Agritech, Vol. 27, No. 4: $152-157$.

Anita, S. 2009. Studi Sifat Fisiko-Kimia, Sifat Fungsional Karbohidrat, dan Aktivitas Antioksidan Tepung Kecambah Kacang Komak (Lablab purpureus (L.) Sweet). (Skripsi). Institut Pertanian Bogor.

AOAC. 2005. Total Monomeric Anthocyanin Pigment Content of Fruit Juice, Beverages, Natural Colorant, and Wines. AOAC Official Method.

Karseno, Handayani, I. dan Setyawati, R. 2013. Aktivitas dan Stabilitas Antioksidan Ekstrak Pigmen Alga. Jurnal Agritech, Vol. 33, No. 4: 371 - 376.

Laila, I. N. 2008. Pengaruh Kultivar dan Umur Perkecambahan Terhadap Kandungan Protein dan Vitamin E pada Kecambah Kedelai (Glycine maxL.)
Merrill. (Skripsi).Universitas Islam Negeri Malang.

Ningsih, W. 2007. Evaluasi Senyawa Fenolik (Asam Ferulat dan Asam pKumarat) pada Biji, Kecambah dan Tempe Kacang Tunggak (Vignaunguiculata). (Skripsi). Institut Pertanian Bogor.

Nurrahman. 2015. Evaluasi Komposisi Zat Gizi dan Senyawa Antioksidan Kedelai Hitam dan Kedelai Kuning. Jurnal Aplikasi Teknologi Pangan 4 (3): $89-93$.

Pertiwi, S. F., Aminah, S. dan Nurhidajah. 2013. Aktivitas Antioksidan, Karakteristik Kimia, dan Sifat Organoleptik Susu Kecambah Kedelai Hitam (Glycine soja) Berdasarkan Variasi Waktu Perkecambahan. Jurnal Pangan dan Gizi, Vol. 4, No. 8: 1 - 8 .

Pessarakli, M. 2001. Handbook of Plant and Crop Physiology. Eastern Hemisphere Distribution. Edisi ke 2. The United States of America.

Rein, M. 2005. Copigmentation Reactions and Color Stability of Berry Anthocyanins. (Disertasi). University of Helsinki.

Sayuti, K dan Yenrina, R. 2015. Antioksidan, Alami dan Sintetik. Andalas University Press. Edisi ke-1. Padang.

Sinha, R. K. 2004. Modern Plant Physiology. Alpha Science International Ltd. Departement Botany of Sciene College, Patna, India.

Sugiharto. 2013. Vitamin. Jurnal Tekonologi Hasil Pertanian Universitas Negeri Lampung: $1-60$.

Suhartatik, N., Karyantina, M., Mustofa, A. dan Cahyanto, M. N. 2013. Stabilitas Ekstrak Antosianin Beras Ketan Oryza sativa var. Glutinosa) Hitam Selama Proses Pemanasan dan Penyimpanan. Jurnal Teknologi Hasil Pertanian, Vol. 33, No. 4: $384-390$.

Sumaryono dan Saptari, R.T. 2015. Pengaruh Matriks Kapsul Terhadap Perkecambahan Benih Sintetik Teh (Camellia sinensis L.). Jurnal 
Bioteknologi dan Bioindustri 83(2): 54 59.

Tanuatmojo, S. 2015. Karakteristik Vitamin Xu, dan Stabilitasnya Terhadap Produk Kombinasi. http://syxgf.blogspot.co.id/2015/02/karakteristikstabilitas-vitamin-dan.html. (22 Maret 2018).

Triana, V. 2006. Macam-macam Vitamin dan Fungsinya dalam Tubuh Manusia. Jurnal Kesehatan Masyarakat, Vol. 1, No. 1: $40-47$.

Winarsi, H. 2010. Protein Kedelai dan Kecambah - Manfaatnya bagi
Kesehatan. Kanisius, Yogyakarta. Hlm. $23-26$.

B. J. dan Chang, S. K. C. 2007. A Comparative Study On Phenolic Profiles and Antioxidant Activity of Legumes as Affected by Extraction Solvents. Journal of Food Science, Vol. 72 (2): 59 - 66.

Zakaria, F. R., Irawan, B., Pramudya, S. M. dan Sanjaya. 2000. Intervensi Sayur dan Buah Pembawa Vitamin C dan Vitamin E Meningkatkan Sistem Imun Populasi Buruh Pabrik di Bogor. Jurnal Bul. Teknol. dan Industri Pangan, Vol. 11, No. 2: $21-27$. 